\title{
Application of FTIR Spectroscopy and Chemometrics for Halal Authentication of Beef Meatball Adulterated with Dog Meat
}

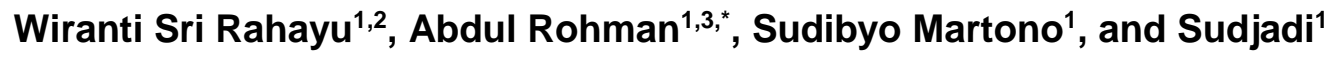 \\ ${ }^{1}$ Faculty of Pharmacy, Universitas Gadjah Mada, Yogyakarta, 55281, Indonesia \\ ${ }^{2}$ Faculty of Pharmacy, Muhammadiyah Purwokerto University, Purwokerto, Indonesia \\ ${ }^{3}$ Research Center of Halal Products, Universitas Gadjah Mada, Yogyakarta, 55281, Indonesia
}

Received August 1, 2017; Accepted September 3, 2017

\begin{abstract}
Beef meatball is one of the favorite meat-based food products among Indonesian community. Currently, beef is very expensive in Indonesian market compared to other common meat types such as chicken and lamb. This situation has intrigued some unethical meatball producers to replace or adulterate beef with lower priced-meat like dog meat. The objective of this study was to evaluate the capability of FTIR spectroscopy combined with chemometrics for identification and quantification of dog meat (DM) in beef meatball (BM). Meatball samples were prepared by adding DM into BM ingredients in the range of $0-100 \% \mathrm{wt} / \mathrm{wt}$ and were subjected to extraction using Folch method. Lipid extracts obtained from the samples were scanned using FTIR spectrophotometer at 4000-650 $\mathrm{cm}^{-1}$. Partial least square (PLS) calibration was used to quantify DM in the meatball. The results showed that combined frequency regions of 1782-1623 $\mathrm{cm}^{-1}$ and 1485-659 $\mathrm{cm}^{-1}$ using detrending treatment gave optimum prediction of DM in BM. Coefficient of determination $\left(R^{2}\right)$ for correlation between the actual value of DM and FTIR predicted value was 0.993 in calibration model and 0.995 in validation model. The root mean square error of calibration (RMSEC) and standard error of cross validation (SECV) were $1.63 \%$ and $2.68 \%$, respectively. FTIR spectroscopy combined with multivariate analysis can serve as an accurate and reliable method for analysis of DM in meatball.
\end{abstract}

Keywords: dog meat; FTIR spectroscopy; chemometrics; halal authentication

\section{ABSTRAK}

Bakso sapi merupakan salah satu makanan favorit bagi masyarakat Indonesia. Saat ini harga daging sapi di pasar Indonesia lebih mahal dibandingkan dengan daging lainnya, sehingga mendorong pedagang nakal untuk mengganti atau memalsukan daging sapi dengan daging yang lebih murah seperti daging anjing. Tujuan penelitian ini adalah untuk mengevaluasi kemampuan spektroskopi FTIR yang dikombinasikan dengan kemometrika untuk identifikasi dan kuantifikasi daging anjing dalam bakso sapi. Bakso disiapkan dengan mencampur daging sapi dengan daging anjing dalam kisaran 0-100\% b/b, dan selanjutnya dilakukan proses ekstraksi dengan metode Folch. Lipid yang diperoleh dipindai dengan spektrofotometer FTIR pada bilangan gelombang $4000-650 \mathrm{~cm}^{-1}$. Kalibrasi multivariat partial least square (PLS) digunakan untuk melakukan fasilitasi kuantifikasi daging anjing dalam bakso. Hasil penelitian menunjukkan bahwa kombinasi bilangan gelombang 1782-1623 $\mathrm{cm}^{-1}$ dan $1485-659 \mathrm{~cm}^{-1}$ memberikan prediksi yang optimum. Nilai koefisien determinasi $\left(R^{2}\right)$ yang diperoleh untuk korelasi antara nilai kandungan daging anjing sebenarnya dan nilai kandungan daging anjing terprediksi dengan spektroskopi FTIR adalah 0,993 dalam model kalibrasi dan 0,995 dalam model validasi. Nilai root mean square error of calibration (RMSEC) dan standard error of cross validation (SECV) masing-masing sebesar 1,63\% dan 2,68\%. Spektroskopi FTIR yang dikombinasikan dengan analisis multivariat yang akurat dan reliabel untuk analisis daging anjing dalam bakso.

Kata Kunci: daging anjing; spektroskopi FTIR; kemometrika; autentikasi halal

\section{INTRODUCTION}

Price of beef is currently more expensive than other meat produce in Indonesian market. Beef is commonly used for preparation of meatball, one of the

* Corresponding author. Tel : +62-87838445216

Email address : abdul_kimfar@ugm.ac.id favorite meat products due to its nutritional value as a good source of protein and its desirable flavor [1-2]. Meatball is a very popular meat-based product among some Asian countries including Indonesia, Vietnam, Myanmar, Malaysia as well as USA and several

DOI: $10.22146 /$ ijc.27159

Wiranti Sri Rahayu et al. 
European countries [3]. Meatball is also known as bakso (Indonesia), bebola (Malaysia), Nem nuong (Vietnam), Kofta (India), Konigsberger klopse (Germany), KungWan (Taiwan and China), Koefte (Turkey), and Polpette (Italy) [4].

Due to the high price and low availability of beef, some unethical meatball producers try to replace or adulterate beef with lower-priced meat. One of the potential meat used for beef adulteration is dog meat. Dog meat (DM) is a potential adulterant as in certain countries like Indonesia DM distribution and price are not well-regulated and thus can be bought at a cheaper price [5]. In addition, some communities in China, Myanmar, South Korea and Vietnam consume dog meats [6].

Addition of DM into beef meatball is a serious matter for certain religions [7]. The followers of Islam and Buddhism are not allowed to consume any products containing DM [8-9]. DM is considered as a non-halal meat according to Islamic law. Indonesian Regulation (Indonesian Act 33, 2014) [21] stipulated that any products (food, cosmetics, personal care and pharmaceuticals) distributed in Indonesia must be halal certified. To implement this act and to assure the authenticity of beef meatball from DM adulteration, some scientists have proposed some analytical techniques for identification of non-halal components including DM in food products [10].

Numerous methods have been developed for analyzing meat types and content in food products, mostly based on polymerase chain reaction (PCR) [11] such as real-time PCR, Taqman-real time PCR and multiplex PCR. Rahman et al. [5] have used PCR assay using cytochrome $b$ gene as a target for detecting DM adulteration in meatball formulation. PCR assay using specific-specific primer on cytochrome b was also used for authentication of commercial Frankfurters from DM [12]. PCR using specific primer and restriction fragment length polymorphism (RFLP) was used for identification of meat sourced from cat, dog, donkey and horse [13]. PCR-based techniques are specific, however, they are time consuming and expensive. Therefore, techniques suitable for screening and rapid analysis of meat products are needed. Several fast testing techniques have been developed based on Fourier transform infrared (FTIR) spectroscopy.

FTIR spectroscopy at optimized wavenumbers region and spectral treatment combined with chemometrics techniques was used for analysis of meat types which were considered as non-halal in meatball. Rohman et al. [1] have analyzed pork in beef meatball using FTIR spectroscopy combined with multivariate calibration of partial least square (PLS). Furthermore, lard in beef meatball broth was fruitfully analyzed using FTIR spectroscopy combined with PLS and principal component analysis (PCA) [14]. FTIR spectroscopy in combination with PLS and PCA has also been successfully used for analysis of rat meat in beef meatball [15]. Soxhlet extraction using petroleum ether or hexane was employed in all these previous studies. The objective of this research was to develop FTIR spectroscopy-based technique for DM analysis in beef meatball using Folch extraction method.

\section{EXPERIMENTAL SECTION}

\section{Materials}

Dog meat (DM) was obtained from some slaughterhouses specific for dog in Yogyakarta, while beef and other meatball ingredients were purchased from a local market in Yogyakarta, Indonesia. All solvents used for analysis were pro-analytical grade. Commercial meatball samples were obtained from local markets and supermarkets in Yogyakarta.

\section{Procedure}

\section{Meatball preparation}

Meatball formulation was prepared according to our previous paper [1]. Beef and DM were sliced and ground separately. The meatball comprised $90 \%$ meat and $10 \%$ additional ingredients including starch, garlic and other spices. DM contents in beef meatballs were varied at $0,2.5,5,10,20,40,50,75$, and $100 \%$. Meatball was made by emulsifying $90 \%$ of meat and adding $10 \%$ of starch and other ingredients to the mixture. The meat mixture was shaped into balls and then cooked in boiling water $\left(100^{\circ} \mathrm{C}\right)$ for $10-20 \mathrm{~min}$.

\section{Calibration and validation samples}

Calibration and validation sample sets were prepared independently. Calibration samples are meatball samples with known concentration of DM ranging from 0 to $100 \%$. Validation samples are samples prepared independently which are different from calibration samples, covering the concentration range of calibration samples. All samples (calibration, validation and commercial) were subjected to lipid extraction and FTIR spectroscopic measurement.

\section{Lipid extraction}

The extraction of lipid in meatball was carried out using Folch method as reported by Pérez-Palacios et al. [16] with slight modification. A $10.0 \mathrm{~g}$ minced meatball sample was mixed with $200 \mathrm{~mL}$ of chloroformmethanol $(2: 1 \mathrm{v} / \mathrm{v})$. The mixture was homogenized using a Turrax homogenizer (10 min, $13.500 \mathrm{rpm}$ ) and filtered. The filtrate was placed in a separating funnel, mixed with $10 \mathrm{~mL}$ distilled water, and shaken 
vigorously. The mixture was allowed to stand until two separate solvent layers were formed. The upper aqueous phase was removed and anhydrous sodium sulphate was then added to the remaining organic phase. The extract was subsequently filtered and concentrated using a rotary evaporator at $40^{\circ} \mathrm{C}$.

\section{FTIR spectra measurement}

Lipid fraction was subjected to FTIR spectral measurement using an FTIR spectrophotometer ABB 3000 (Canada), equipped with deuterated triglycine sulphate as the detector. Sampling technique used was horizontal attenuated total reflectance (HATR) using ZnSe crystal. Each sample was scanned 32 times at 8 $\mathrm{cm}^{-1}$ resolution between $4000-650 \mathrm{~cm}^{-1}$. After each scanning, a new reference of air background spectrum was taken and all spectra were corrected against the air spectrum. FTIR spectra were recorded as absorbance values at each data point in triplicate.

\section{Statistical analysis}

All statistical analysis including cross validation using leave-one-out technique was performed using Horizon MB software (included in the FTIR spectrophotometer). Some parameters including coefficient of determination $\left(R^{2}\right)$, root mean square error of calibration (RMSEC), root mean square error of prediction (RMSEP) and predicted residual errors of sum square (PRESS) were calculated.

\section{RESULT AND DISCUSSION}

Fig. 1 revealed FTIR spectra of lipid fraction extracted from meatball samples composed of $100 \%$ beef and $100 \%$ dog meat. This extraction method used the mixture of water and chloroform : methanol (2:1) followed by washing with $0.9 \% \mathrm{KCl}$. Using Folch method, all classes of lipids (nonpolar, semipolar and polar) were extracted. Folch method is a standard extraction method for lipid and is well established to determine total lipids content. However, the use of chloroform has the adverse effects toward environment [17-18]. The position of FTIR spectral peaks are influenced by lipid and moisture contents of the sample [8]. As different extraction methods will give varied contents of lipid and moisture, a new model for FITR quantification needs to be developed for Folch extraction applied to the meatball samples.

All peaks and shoulders of FTIR spectra are characteristics of triacylglycerol (TG). This is not surprising, because fats extracted from beef and DM are mainly composed (nearly 95\%) of TG. Both FTIR spectra of beef and DM look very similar, however, with more detailed investigation, there are some slight differences, especially in the fingerprint region $\left(1500-650 \mathrm{~cm}^{-1}\right)$. Some peak intensities in this region are different. This is true because FTIR spectra of samples are fingerprint in nature which can be understood that there are no two different samples having same FTIR spectra. The peak height ratio at $1118 \mathrm{~cm}^{-1 / 1098} \mathrm{~cm}^{-1}$ due to $\mathrm{C}-\mathrm{O}$ stretching vibration is higher in beef than that in DM. This difference can be exploited for quantification model of DM in beef meatball. Functional groups responsible for infrared absorption of the lipid fraction was compiled in Table 1.

FTIR spectral treatments were optimized to give the best prediction model that provides the highest value of coefficient of determination $\left(R^{2}\right)$ and the lowest

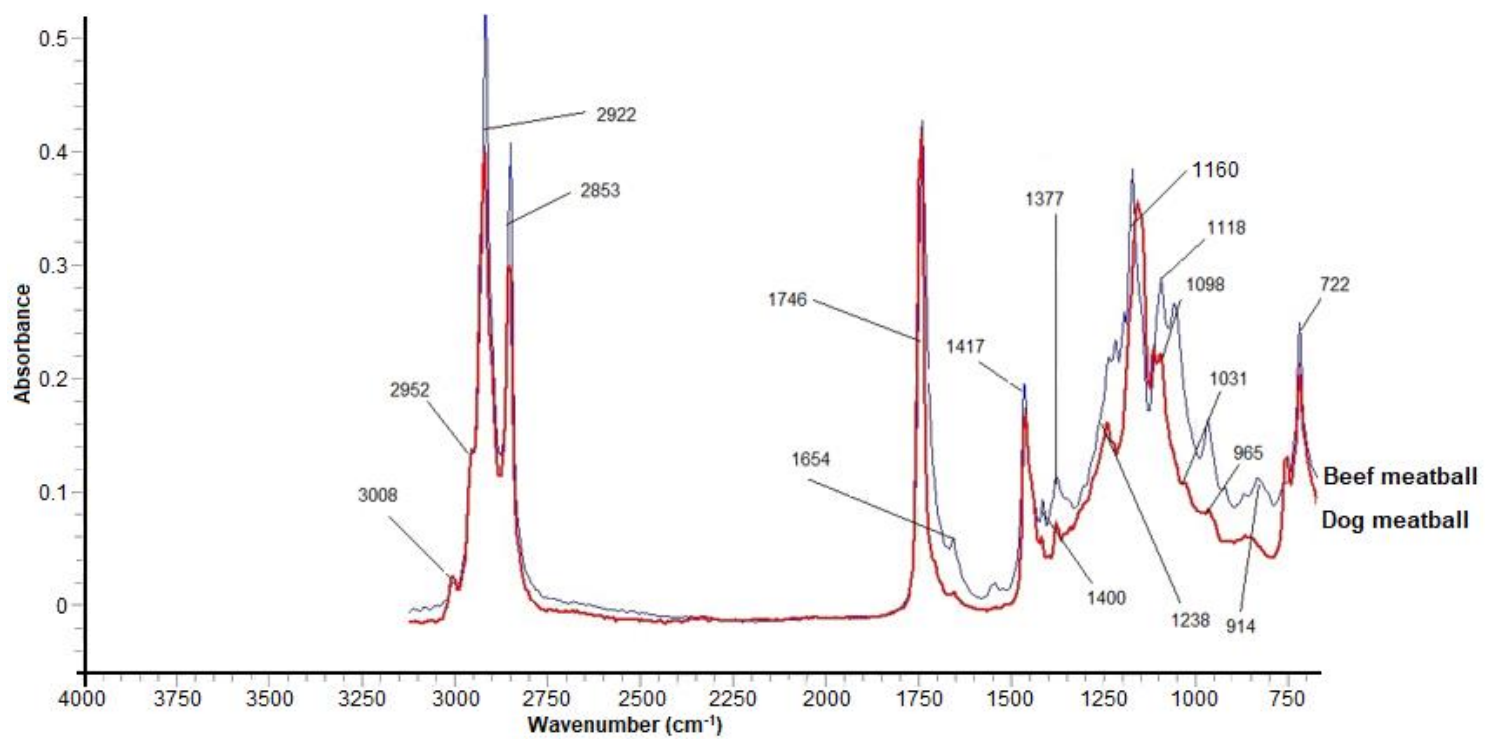

Fig 1. FTIR spectra of lipid fraction extracted from $100 \%$ beef meatball (beef) and $100 \%$ dog meatball (dog), scanned at $4000-650 \mathrm{~cm}^{-1}$ 
Table 1. IR peak frequencies and functional groups present in lipid fractions extracted from beef and dog meat [1920].

\begin{tabular}{|c|c|c|}
\hline Frequency $\left(\mathrm{cm}^{-1}\right)$ & Functional group & Mode of vibration \\
\hline 3008 (b) & $=\mathrm{C}-\mathrm{H}($ cis $)$ & Stretching \\
\hline 2952 (s) & $-\mathrm{CH}$ (methyl) & Stretching (asymmetric) \\
\hline 2922 (b) & - $\mathrm{CH}$ (methylene) & Stretching (asymmetric) \\
\hline 2853 (b) & -CH (methylene) & Stretching (symmetric) \\
\hline 1746 (b) & $-\mathrm{C}=\mathrm{O}$ (ester) & Stretching \\
\hline 1654 (b) & $-\mathrm{C}=\mathrm{C}(\mathrm{cis})$ & Stretching \\
\hline 1465 (b) & -CH (methylene; methyl) & Bending (scissoring) \\
\hline 1417 (b) & $=\mathrm{C}-\mathrm{H}$ (cis disubstituted olefins) & Bending (rocking) \\
\hline 1400 (b) & Difficult to be assigned & Bending \\
\hline 1377 (b) & -CH (methyl) & Bending (symmetric) \\
\hline 1238 (b) & $-\mathrm{C}-\mathrm{O} ;-\mathrm{CH}_{2-}^{-}$ & Stretching; bending \\
\hline 1163 (b) & $-\mathrm{C}-\mathrm{O} ;-\mathrm{CH}_{2-}$ & Stretching; bending \\
\hline 1118 (b) & $-\mathrm{C}-\mathrm{O}$ & Stretching \\
\hline 1097 (b) & $-\mathrm{C}-\mathrm{O}$ & Stretching \\
\hline $1031(\mathrm{~s})$ & $-\mathrm{C}-\mathrm{O}$ & Stretching \\
\hline 965 (b) & $-\mathrm{HC}=\mathrm{CH}-($ trans $)$ & Out of plane \\
\hline 914 (b) & $-\mathrm{HC}=\mathrm{CH}-($ cis $)$ & Out of plane \\
\hline 722 (b) & $-\left(\mathrm{CH}_{2}\right)_{\mathrm{n}} ;-\mathrm{HC}=\mathrm{CH}-(\mathrm{cis})$ & Bending (rocking) \\
\hline
\end{tabular}
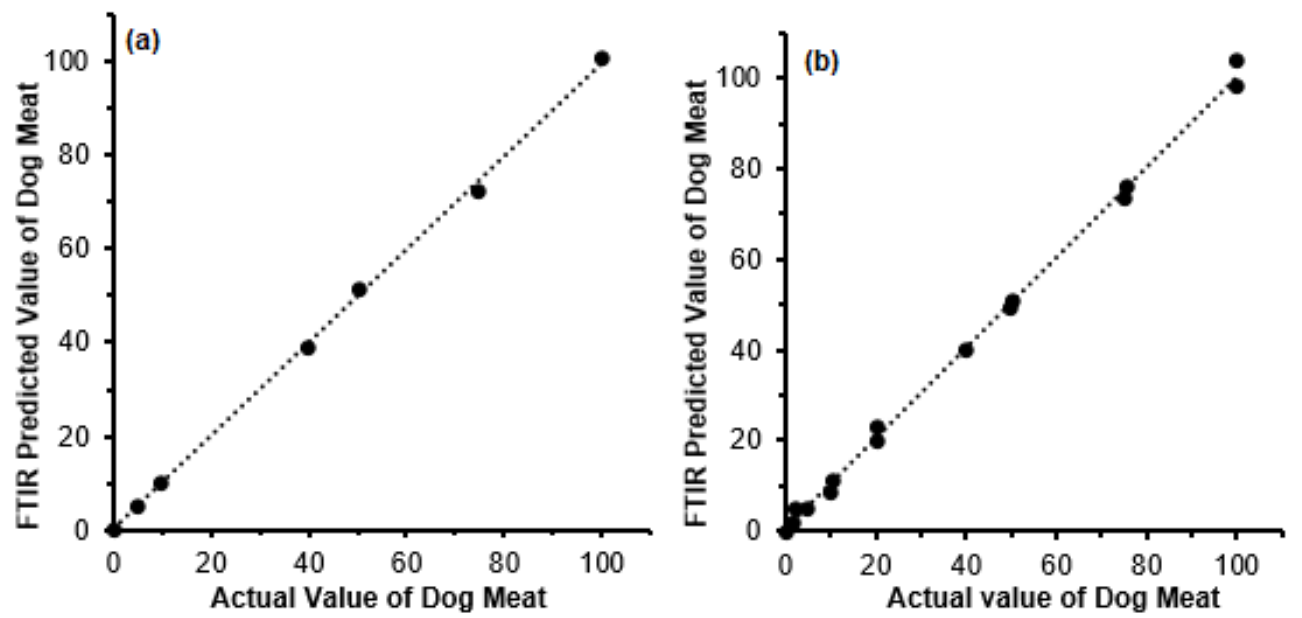

Fig 2. Correlation between actual value (x-axis) of dog meat (\%wt/wt) and FTIR predicted value ( $y$-axis) of dog meat (\% wt/wt), (a) calibration model; (b) validation model

Table 2. Performance of partial least square (PLS) calibration for quantification of dog meat in beef meatball.

\begin{tabular}{|c|c|c|c|}
\hline Model & Equation & $\mathrm{R}^{2}$ & Error \\
\hline Calibration & $Y=0.9876 x+0.4669$ & 0.9957 & RMSEC $=1.63 \%$. \\
\hline Validation & $Y=1.0242 x+0.12$ & 0.9987 & RMSEP $=2.63 \%$ \\
\hline
\end{tabular}

values of root mean square error of calibration (RMSEC) and prediction (RMSEP). Finally, the combined frequency regions of $1782-1623 \mathrm{~cm}^{-1}$ and $1485-659 \mathrm{~cm}^{-1}$ using detrending treatment gave the optimum prediction model. The levels of dog meat in meatball either in calibration or validation samples were determined using partial least square (PLS). The coefficient of determination $\left(\mathrm{R}^{2}\right)$ obtained for correlation between actual value of DM and FTIR predicted value was 0.993 in the calibration model and 0.995 in the validation model. The root mean square error of calibration (RMSEC) obtained is $1.63 \%$. Fig. 2 showed equations obtained from correlating the actual value $(x$-axis) of $\mathrm{DM}$ to the FTIR predicted value ( $y$-axis) during calibration (A) and validation (B) processes. Statistical parameters describing the performance of external validation are $R^{2}(0.995)$ and root mean square error of prediction (RMSEP) of $2.63 \%$. Table 2 compiled the 
statistical results of the PLS model for both calibration and validation.

Besides external validation using independent samples, internal validation using cross validation with leave-one-out technique (LOOT) was also carried out. During LOOT, one of the calibration samples was removed, and the remaining calibration samples were used for constructing a new calibration model. This new model was subsequently used to predict the value of the removed one. This process was repeated until all calibration samples were removed one by one, and recalculated. The statistical parameter used to assess the LOOT was standard error of cross validation (SECV). The SECV value was $2.68 \%$. The high value of $\mathrm{R}^{2}$ and low value of RMSEC and SECV indicated that the developed method was accurate and precise. Therefore this method can be used for estimating DM content in beef meatball.

\section{CONCLUSION}

FTIR spectroscopy in combination with multivariate calibration using partial least square was succesfully developed and validated for DM analysis in beef meatball. Combined frequency regions of 1782-1623 $\mathrm{cm}^{-1}$ and $1485-659 \mathrm{~cm}^{-1}$ with detrending treatment gave the optimum prediction of DM quantity in beef meatball.

\section{ACKNOWLEDGEMENT}

The authors thank the Ministry of Research and Higher Education, Republic Indonesia for financial assistance during conducting this research. The research was funded through Penelitian Unggulan Perguruan Tinggi (PUPT) grant, contract number: 617/UN1-P.II/LT/DIT-LIT/2016 awarded to Prof. Dr. Abdul Rohman.

\section{REFERENCES}

[1] Rohman, A., Sismindari, Erwanto, Y., and Man, Y.B.C., 2011, Analysis of pork adulteration in beef meatball using Fourier transform infrared (FTIR) spectroscopy, Meat Sci., 88 (1), 91-95.

[2] Soares, S., Amaral, J.S., Oliveira, M.B.P.P., and Mafra, I., 2014, Quantitative detection of soybean in meat products by a TaqMan real-time PCR assay, Meat Sci., 98 (1), 41-46.

[3] Ali, M.E., Hashim, U., Dhahi, T.S., Mustafa, S., Man, Y.B.C., and Latif, M.A., 2012, Analysis of pork adulteration in commercial burgers targeting porcine-specific mitochondrial cytochrome B gene by TaqMan probe real-time polymerase chain reaction, Food Anal. Methods, 5 (4), 784-794.
[4] Huda, N., Shen, Y.H., Huey, Y.L., Ahmad, R., and Mardiah, A., 2010, Evaluation of physico-chemical properties of Malaysian commercial beef meatballs, Am. J. Food Technol., 5 (1), 13-21.

[5] Rahman, M.M., Ali, M.M., Hamid, S.B., Mustafa, S., Hashim, U., and Hanapi, U.K., 2014, Polymerase chain reaction assay targeting cytochrome $b$ gene for the detection of dog meat adulteration in meatball formulation, Meat Sci., 97 (4), 404-409.

[6] Podberscek, A.L., 2009, Good to pet and eat: The keeping and consuming of dogs and cats in South Korea, J. Social Issues, 65 (3), 615-632.

[7] Khattak, J.Z.K., Mir, A., Anwar, Z., Wahedi, H.M., Abbas, G., Khattak, H.Z.K., and Ismatullah, H., 2011, Concept of halal food and biotechnology, Adv. J. Food Sci. Technol., 3 (5), 385-389.

[8] Rahmati, S., Julkapli, N.M., Yehye, W.A., and Basirun, W.J., 2016, Identification of meat origin in food products-A review, Food Control, 68, 379390.

[9] Rohman, A., and Man, Y.B.C., 2012, Analysis of pig derivatives for halal authentication studies, Food Rev. Int., 28 (1), 97-112.

[10] Mursyidi, A., 2013, The role of analytical chemistry in Halal certification, J. Food Pharm. Sci., 1 (1), 14.

[11] Raharjo, T.J., Alfiraza, E.N., Enjelina, E., and Pranowo, D., 2017, Validation of a non-specific dye real-time PCR assay for porcine adulteration in meatball using ND5 primer, Indones. J. Chem., 17 (2), 167-174.

[12] Ali, M.E., Rahman, M.M., Hamid, S.B.A., Mustafa, S., Bhassu, S., and Hashim, U., 2014, Caninespecific PCR assay targeting cytochrome b gene for the detection of dog meat adulteration in commercial frankfurters, Food Anal. Methods, 7 (1), 234-241.

[13] Abdel-Rahman, S., El-Saadani, M., Ashry, K., and Haggag, A., 2009, Detection of adulteration and identification of cat's, dog's, donkey's and horse's meat using species-specific PCR and PCR-RFLP techniques, Aust. J. Basic Appl. Sci., 3 (3), 17161719.

[14] Kurniawati, E., Rohman, A., and Triyana, K., 2014, Analysis of lard in meatball broth using Fourier transform infrared spectroscopy and chemometrics, Meat Sci., 96 (1), 94-98.

[15] Rahmania, H., Sudjadi, and Rohman, A., 2015, The employment of FTIR spectroscopy in combination with chemometrics for analysis of rat meat in meatball formulation, Meat Sci., 100, 301305.

[16] Pérez-Palacios, T., Ruiz, J., Martín, D., Muriel, E., and Antequera, T., 2008, Comparison of different 
methods for total lipid quantification in meat and meat products, Food Chem., 110 (4), 1025-1029.

[17] Harino, H., Fukushima, M., and Kawai, S., 2000, Accumulation of butyltin and phenyltin compounds in various fish species, Arch. Environ. Contam. Toxicol., 39 (1), 13-19.

[18] Kondo, T., Yamamoto, H., Tatarazako, N., Kawabe, K., Koshio, M., Hirai, N., and Morita, M., 2005, Bioconcentration factor of relatively low concentrations of chlorophenols in Japanese medaka, Chemosphere, 61 (9), 1299-1304.

[19] Guillén, M.D., and Cabo, N., 1997, Characterization of edible oils and lard by Fourier transform infrared spectroscopy. Relationships between composition and frequency of concrete bands in the fingerprint region, J. Am. Oil Chem. Soc., 74 (10), 12811286.

[20] Lerma-García, M.J., Ramis-Ramos, G., HerreroMartínez, J.M., and Simó-Alfonso, E.F., 2010, Authentication of extra virgin olive oils by Fouriertransform infrared spectroscopy, Food Chem., 118 (1), 78-83.

[21] Indonesian Act No. 33. 2014, Halal Products Assurance (Jaminan Produk Halal), http://www.dpr.go.id/dokjdih/document/uu/1615.pdf, accessed on 25 February, 2017. 